\title{
Public Policy and Foucaultian Critique: Towards a Happy Marriage?
}

\author{
Kaspar Villadsen (Corresponding author) \\ Department of Management, Politics and Philosophy, Copenhagen Business School \\ Porcelænshaven 18a, 2000 Frederiksberg, Denmark \\ Tel: 45-2721-3264Ｅ-mail: kv.lpf@cbs.dk
}

Mads Peter Karlsen

Department of Systematic Theology, University of Copenhagen

Købmagergade 44-46, DK - 1150 Copenhagen K, Denmark

Tel.: 45-3532-2614Ｅ-mail: mpk@teol.ku.dk

Received: November 21, 2011

Accepted: February 3, 2012 Published: March 1, 2012

doi:10.5539/res.v4n1p138

URL: http://dx.doi.org/10.5539/res.v4n1p138

\begin{abstract}
This article suggests that certain intertwinements can be discerned between contemporary public policies and post-structural thinking, emblematically represented by Foucault and scholars drawing upon his work. The article demonstrates that the post-structural perspective on power, while recognising its strengths and efficacy, confines observers to a particular form of analytical critique, which sets specific limits for what can be observed and debated. The position of Nikolas Rose is discussed with a specific attention to his diagnosis of the adoption of 'community' as a governmental category and his understanding of the relationship between power and critique. A significant challenge for this form of critique is the recent embracing of concepts of 'diversity' and 'pluralism', both in welfare reforms and service arrangements. Another difficulty is posed by how to engage with the material conditions of critical practice which implies analytical critique and resistance through creative self-formation. The article suggests some dislocations of the generalized Foucaultian position on public policy that seem increasingly necessary in the present situation.
\end{abstract}

Keywords: Public policy, Foucault, Post structuralism, Critique, Diversity

\section{Introduction}

One thing we have learnt after post-structuralism is that knowledge is immanent to the field of practice and power relations with which it engages. The article discusses this sort of immanence in respect to critical knowledge of public policy, especially of the post-structural variety. It poses the following question: what happens when the forms of critique and notions of power underlying that critique, themselves get taken up by domains of practice and policy? Are we then to dismiss post-structural critique as mere ideology? Or are we able to adapt and modify our analytical framework to show how this critique becomes a part of the practice of public policy itself? This article pursues the latter approach while taking into consideration a number of reservations against post structural critique voiced particularly by neo-Marxist critics.

First, we outline the post structural conception of critique of political and administrative authority, foregrounding Michel Foucault's conception of power as paradigmatic in this regard. Second, we discuss recent attempts to theorize the immanent relationship between social critique and the power being criticized, assessing insights proposed by Nikolas Rose. Third, a case study done by one of Rose's colleagues is discussed in some detail with a focus on its lack of attention to the social conditions for exercising critique. Fourth, we conclude by suggesting two displacements of the poststructuralist position with respect to notions of diversity embedded in the romance of civil society or user sensitive services, and with respect to the material, social and political conditions of the Foucauldian ideal of creative self-fashioning as a form of critical practice. A significant aim of the article is to point to a way of combining post-structural critique with elements of a more traditional social policy focus on economic distribution and recent considerations of human capability. 


\section{Post Structural Theory as a Smoke Screen?}

In recent years, the general relationship between critique and the objects of critique has been tackled by a range of academics of various persuasions, including Michael Hardt and Antonio Negri (2001), Slavoj Zizek (1999), and Mitchell Dean (2001). A critical observer of social policy, Peter Taylor-Gooby, took a radical stance on the apparent affinities between social policies and poststructuralist thinking. He argued that postmodern theorizing has come to serve as an "ideological smoke screen" obscuring fundamental reforms of social policy such as financial cut-backs, privatizations and dismantling of services (Taylor-Gooby, 1994: 385). The postmodern focus on diversity and particularism allegedly ignores the universalizing advance of liberal market principles. A range of neo-Marxist theorists like Frederic Jameson, Terry Eagleton, Alex Callinicos and, more recently, Žižek have argued that postmodernism constitutes 'the cultural logic of late-capitalism' to quote Jameson's renowned essay (Jameson, 1984; Eagleton, 1984; Callinicos, 1991; Žižek, 1999). And Žižek accuses "today's critical theory" in the form of cultural studies, post-colonial studies and gender studies of "performing the ultimate service for the unrestrained development of capitalism by actively participating in the ideological effort to render its massive presence invisible" (Žižek, 1999: 218).

We will not go as far as these claims, but we contend that the post-structural program for analysing and exercising power has - like any other theoretical-practical program - its particular consequences and costs. We further agree that it is worthwhile questioning if the particular 'epistemological gaze' inherent to post structural thinking may presently serve a number of strategic, or even ideological, functions in as far as they are adopted by political programs and administrations.

Taken in outline, under the post-structural 'gaze', the subject emerges as decentred and potentially self-fashioning, truth appears as provisional, localized and culturally embedded, and, ceasing to be embodied in institutions or persons, power is dispersed and capillary, fluctuating in micro-relations. While this gaze has yielded many important insights, we suggest that it confines the observers to a particular form of critique, implicitly imposing certain limitations on the type of observations that can be made about public policies. If post structural theorizing serves as a smoke-screen for the exercise of power, it would be, we content, in its way of limiting analytical critique. The following section interrogates this 'gaze'-the framework of observation inherent in the post-structural critique of power-in greater detail.

\subsection{The post-structural conception of power}

Let us be a bit more precise about how the post-structural conceptualization of power structures the observing gaze. Most post-structural thinkers would endorse the above sketched characteristics of power; they would see power as non-localizable (rather than possessed by a power-holder), microphysical (rather than descending hierarchically), reversible (rather than one-directional), productive (creating capacities rather than merely suppressing), and exercised on free subjects (thus depending on the active agency of the governed for its results). Recall further that post-structural thinkers would typically abstain from judging a particular form of power as 'good' or 'bad' in itself, emphasizing the contextual nature of such evaluations, i.e., their dependence on the function power plays in specific situations. This means, finally, that normative judgements cannot be imposed on a given context from an external, 'pure' position; instead, a critical position on power needs to be established within the specific context and be informed by the voices of the involved.

Foucault is often counted as the poststructuralist thinker on power, although he rejected the poststructuralist label (1999: 448). In his investigations of the historical descent of modern welfare practices Foucault distinguished earlier forms of 'reductive' power from modern 'productive' power by the fact that the latter aimed to foster capacities in the governed rather than simply controlling or repressing them (Foucault, 1990; Foucault, 1995). With his concepts of 'biopower', 'pastoral power' and 'governmental power' Foucault emphasized that modern power recognizes that it does not constitute the source of its effects and is thus looking for ways to mobilize energies, processes and movements inherent in the objects of government (Foucault, 2008).

Foucault's conceptualization of power indeed proved efficient to grasp the more subtle forms of power exercised in modern welfare states, that is, the forms of power that operate 'at a distance' through free subjects (but also through non-government groups and organizations) by harnessing their capacities and taking their aspirations and tactics into account. The justification for this emphasis on subtle and productive forms of power was not that more brute forms of economic exploitation or political-ethnic dominance had ceased to exist, but rather that the former - exercised in a wide variety of micro-political everyday relations - was more difficult to spot and had been severely underestimated as a consequence of inadequate conceptual tools in conventional theories of power (Foucault, 1982). Thus Foucault: "Nowadays, the struggle against forms of subjection - against the submission 
of subjectivity - is becoming more and more important, even though the struggle against forms of domination and exploitation has not disappeared. Quite the contrary." (Foucault, 1982: 782).

At the same time, Foucault's attempt to dislodge himself from Marxist categories like 'class struggle' and 'relations of production', gave his 'analytics of power' a perhaps overplayed reluctance to ever consider whether power relations, or power-knowledge regimes, might in some instances be helpfully conceived as rooted in underlying structures, the economy, or in the state apparatus as an anchor point of power (Foucault, 1980b; 1980c). Instead, Foucault enjoined us to see power as emergence, that is, as played out in networks of 'surface'-relations that connect up power and knowledge in specific ways. These may well take the shape of social strategies which stand in a relation to the development of capitalistic modes of production as in the case of the rise of modern 'bio-power' (Foucault, 1990: 140-141), but they are in Foucault's view strictly non-reducible to the basis/superstructure model (Foucault, 1980a: 118).

Few public policy commentators inspired by Foucault or French post-structuralism more broadly have seriously discussed the question of whether the mundane power-technologies that they study might be predicated upon broader discursive transformations or structural conditions, and this avoidance may be explained, at least partly, by the political-historical context in which key post-structural assumptions and concepts were formed. Again, the concern of influential poststructuralist theories to dislodge themselves from Marxist theory had the side-effect of creating a certain phobia for talking about 'the state' or 'the economy', since this would immediately make them prey to accusations of reductionism - roughly speaking, there was a fear of reductionism with respect to power relations in the case of Foucault and governmentality writers (Rose and Miller, 1992), and with respect to economy and class in case of Ernesto Laclau and discourse theorists (Laclau, 1977). For this reason, the economy and the state became 'no-go' domains for most poststructuralist analysis (Stäheli, 2007), and that may account for why this conceptual framework has showed itself less apt to study the broader structures within which struggles around subjectivity are played out in public policy and welfare provision.

Admittedly, these historical conditions only make up one element in a broader and more complex process, whereby post structural policy studies became micro-analytical, conceived power as non-substantial, and adopted immanent critique. It is outside the scope of this paper to interrogate exhaustively why concepts of power akin to post-structural thinking emerge in public policy programs at this particular juncture. In passing, however, we may mention that the 'anti-authoritarian' public policy initiatives of the 1990s and onwards, exemplified above, were merely the culmination of a long lasting critique of the welfare state's alleged rigidity and insensitivity to various citizens and groups (Karlsen \& Villadsen, 2008). Second, from the early 1980s, the domain of those social theories that, more or less directly, inform social research and public policy underwent a re-orientation under the influence of postmodern theorizing, dissolving the base for true knowledge and the exercise of expert power. Third, one may suggest that the success of the liberal welfare state rests on its capacity to continuously incorporate the critique aimed at it and promise improvements (Dean, 1999). We discuss this claim more closely below, but the recent emergence of 'post-structural' policies and reform initiatives could indeed be seen as part of a process where the liberal welfare state once again succeeds in adapting to, and incorporating, the most recalcitrant of critique.

\section{Nikolas Rose: The Governmental Quest for Communities}

Over the last few years there has been significant discussion about the critical potential and effects of social theory, suggesting an impasse or a crisis in existing conceptions of critique (Honneth, 2000; Hardt and Negri, 2001; Boltanski and Chiapello, 2005). Central to this debate are attempts to theorize more thoroughly the relation between social critique and the 'powers' being criticized. Hence a number of contributors have tried to conceptualise - although in different ways - how critique is adopted and becomes part of the internal workings of the systems it set out to criticise. Offering important insights into the current conditions and possibilities for exerting power as well as practising critique, these studies are of great relevance to our investigation into the relationship between post structural theory and public policy. We will focus on a piece by Nikolas Rose that indicates key problems in the critique/power circuit, such as power's constant incorporation of its 'outside', its embracement of diversity, and the resulting problem of identifying power.

Nikolas Rose is a key representative of a loosely delineated stream of research termed govenmentality studies which has drawn upon the analytical framework offered by Foucault to develop tools for examining transformations in contemporary ways if exercising power in 'advanced liberal welfare states' (Barry et al., 1996). Particularly interesting for present purposes, these studies emphasise the remarkable capacity of liberal forms of governing to continuously accommodate itself to critique and promise to govern better, wiser and more efficiently (Barry, 1996; Dean, 1999). Liberal government, on this view, is a system for thinking about power 
that has an internal self-problematizing impetus which makes it sceptical towards planning, in depth regulation and control of human affairs, while it nevertheless intervenes to 'secure' what is taken to be the 'natural processes' of the economy or civil society. This 'double-gaze' of liberalism that observes its objects as quasi-natural leads to a fertile creativity in criticising existing forms of governing and inventing new ones (Gordon, 1991).

Nikolas Rose effectively used this figure of ontology/creation in an analysis of how 'community' in the 1990s began to supersede 'the social' as a key governmental category (1996). The analysis demonstrates how a category that was originally applied in social critique by activists later became appropriated by governmental authorities for various strategies of planning, control and risk minimization. These strategies revolved around the imaginary of 'an awakening' of a lost community with potential for crime prevention, health promotion, neighbourhood revitalization and more. Rose says: "This idea of community as lost authenticity and common belonging was initially deployed in the social field as part of the language of critique and opposition directed against remote bureaucracy. Community activists were to identify not with the welfare system which they saw as degrading, policing and controlling, but with those who were the subjects of that system - the inhabitants of the housing estates, projects and ghettos" (Rose, 1996: 332). Community as category of resistance and critique was prominent in the 1960s but it quickly began to be utilized by authorities to represent, problematize and intervene in difficult cultural and geographic zones. Rose observes that community became governmental once it was made technical and entered into the vocabularies and classifications of authorities (1996: 334). Sociologists accelerated this process by intensifying their investigations of social life in terms of community and its decay and potentials. In brief, what began as a category of resistance was, within a rather brief time span, transformed into a tool for governmental intervention through the work of expert discourse.

Significantly for our purposes, Rose's analysis seems to suggest that the reconfiguration of political rationality - from national planning to government trough diverse communities-should not be seen as either the result of centralized authorities implementing from above, or as the product of a diversification of interest groups, local communities and regions aiming for more autonomy. Rather, the adoption of the category of communities by governmental policies resulted from a dynamic interplay between the knowledge generated by activists and social scientists and diverse authorities aspiring to govern in a more culturally sensitive, empowering, and diversified fashion. In short, there was a circuit, a mutual relation, between critique and power. The strength of the governmentality writers' conceptualization of the power/critique-cyclus is that it eschews any totalising conceptualizations of this mechanism (Hardt and Negri, 2001) and rather emphasizes the contingence and singularity of the intertwinements of political-administrative power and social critique.

Thus, any kind of conduct or program, including ones that we may at some point describe as progressive, critical or 'counter-power', always runs the risk of becoming hegemonic (Foucault, 1990). Therefore, what counts as resistance or critique cannot be defined in advance but depends on the specific power-configuration in each particular instance. Social policy studies have debated whether mainstream social policy has adopted features from 'critical social policy' resulting in a regrettable blurring of the two (e.g. Hearn, 1982). From our perspective, however, an a priori fixation of one position as 'the critical' would lock us up in a too inflexible position with respect to which inputs we might consider helpful, provocative or stimulating in a given context, for a given problem. Foucault offers a framework that allows us to be practical and unromantic in relation to any social practice by questioning which orderings of the social contains the greatest danger. At the same time, one must admit that followers of a Foucaultian approach like Rose have a tendency to ignore the social and structural factors foregrounded by more conventional sociology and social policy studies as conditioning individual and collective agents' possibilities of undertaking critical practices. In what follows, we examine this omission and its consequences in a concrete study offered by one of Rose's former Ph.D. students and co-workers. 3.1 Creative self-practice versus institutional fixation

What, then, would it look like if Rose's position was to serve as a guideline for specific studies of non-state agents' creative self-fashioning? Lisa Blackman's work on the self-help group, The Voice Hearers' Network (or VHN) seems to take up exactly this task. It draws upon Rose and the governmentality-approach combined with poststructural theory on identity and thus serves as an illustrative example (Blackman, 1998; 2000; 2001). The VHN is a non-state group of voice-hearers which practises ways of re-living and re-conceptualizing voice-hearing that stand in radical opposition to the psychiatric system. Indeed, a key objective is to loosen the grip of institutional psychiatric expertise on the voice-hearers in order to reinsert them into society. A self-help manual produced by members of the network clearly states this: "It is important to see yourself as an individual rooted in society and not as a patient rooted in psychiatry" (Coleman and Smith, 1997: 16). Echoing Rose's 
position, Blackman's study emphasizes the potentials of alternative and diverse forms of self-formation which takes place in a 'community' outside of the state apparatus.

Blackman's description of the VHN follows a striking dualistic pattern in that every characteristic of the self-help group is defined in direct opposition to its negative counter-part of the modern 'psy-sciences' and their institutionalization as state psychiatry (2000: $57 \mathrm{ff}$ ). In fact, one is tempted to read this pattern through a communication analysis in the spirit of Niklas Luhmann and similar thinkers who view communication as pure binary distinctions. According to Spencer-Brown, 'We take as given the idea of distinction and the idea of indication, and that we cannot make an indication without drawing a distinction (1969: 1). All of Blackman's observations would appear as exactly that: an indication within the framework of a difference.

That Blackman's observations need the other side of the distinction becomes clear when we examine the various qualities of the self-help group. First, the VHN conceptualizes voice-hearing as a gift and a sign of sensitivity as opposed to seeing it as lack and merely a sign of disease (Blackman, 2000: 69). Second, in the modern psy-sciences mental distress emerges as an irrational threat to rational self-control that needs medical and custodial supervision. Contrasting this negation and denial, the VHN adopts a practice of acceptance and integration of voices which allows voice-hearers to transform their relation to the experience (Blackman, 2000: 60). Third, where the psychiatric regime conceives of voices as random, uninvited assaults on the patient's psychological functioning, VHN re-configures voices as a capacity that can be controlled and valued as a key site for spiritual development and transformation" (Blackman, 2000: 63). Finally, Blackman depicts a radical difference between the psychiatric discourse which turns the voice-hearer into a passive recipient of a disease, and the telepathic knowledge used by VHN which constructs them as active persons who have a gift a special sensitivity that they can act upon (2000: 66).

This should suffice to get a sense of Blackman's analytical approach and critical orientation. She indicates positively diverse practices of embodiment of ethics, which she views as sources of an excess of significations and possible ways of shaping subjectivity. Her point of attack, then, is of course those regimes which fixate and restrict this potential for fluid, heterogeneous identity-work. Her research "was a strategic attempt to de-naturalise and de-stabilise 'psy' understandings and show that they are historical contingent and not natural." (Blackman, 1998: 40). One may question, however, the political implications of this view: Is it only the psy-disciplines and their institutional truths whose unnaturalness needs to be displayed? And, perhaps more important, it seems that on this view the power of psychiatry is exclusively negative and restrictive - contrary to Foucault's myriad injunctions about power as positive and productive. It seems that it does not allow for the possibility that psychiatric institutions in some cases crucially support or facilitate experimental practices such as VHN. Further, psychiatry is supposedly deeply ingrained in the disciplinary, modern project, found in schooling, legal and health care systems, which normalizes according to "desired images of selfhood" (Blackman, 2000: 70). But could it be that psychiatry is not simply there to produce 'disciplined man', but is indeed also a reaction to something, or someone with particular sufferings?

Blackman's valorization of resistance to state psychiatry which attempts to create new spaces outside its framework corresponds with Rose in so far as they both operate with a sociality where material determinants, bodily needs, welfare, rights and institutions play either no role or an unambiguous negative one. She problematically follows Rose in her complete avoidance of considerations about conditions (in terms of rights, welfare, security, medication and so on) that may need to be in place for groups and individuals to be able to exercise those experimental self-practices that she celebrates. Like Rose she also fails to consider whether resistance performed by welfare clients would not normally need to inscribe itself within the welfare institutions and their categories of knowledge in order to become effective facilitate change. But perhaps most importantly, there is nothing in Blackman's critique that would prevent it from serving as inspiration for a governmental reform programs in a neo-liberal vein that purport to make psychiatric institutions more 'responsive' to their users. One the one hand, such reforms could positively diversify services to suit different users with diverse needs, and yet, on the other, it could mean that services and medication would be downscaled - services that perhaps are essential for psychiatric patients' fundamental well-being and thus constitute a necessary condition for experiments with self-formation commemorated by Blackman and other governmentality writers.

\section{Critique and Contemporary Public Policy}

The above discussions of Nikolas Rose and Lisa Blackman point to two major questions for those who take up a critical engagement with public policies from a post structural position. First, should we maintain the Foucaultian micro-analytics of power, with its particular strengths and blind spots, or should our gaze for observing power be expanded, or dislocated somewhat, in light of recent developments in welfare reforms? 
Could it be developed to include more conventional social policy problems of rights, welfare and structural conditions? Second, what type of critique is most needed presently in light of the embracement of concepts like 'diversity' and 'pluralism' in public policy programs, manifested for instance in the rising trend of 'minority' and 'identity politics'? What should be the role of analytical critique when we see that such concepts akin to Foucaultian and post structural theorizing are being taken up by administrative and political programs that this critique seeks to target?

First, however, let us briefly consider the implications of a continuation of the generalized Foucaultian approach in critical policy studies. In broad terms, it would undoubtedly consist in further investigations of 'the governmentality' of public policies and services. That is, the analysis would insist on extending beyond the law and extra-judicial forms of power, to focus on how particular forms of knowledge and modes of generating knowledge are co-opted by welfare state administrations and utilized in strategies for forming subjectivities. A continuation would also - and probably to a higher extent - consist in careful analysis of all those mundane power technologies that seek to shape not only subjects, but also relations and institutions within service arrangements of contemporary welfare states. This emphasis on grasping the politics at stake in the small technologies aimed at 'producing competent citizens' is expressed illustratively by Barbara Cruikshank when she argues that "democratic politics is not so much out there, in the public sphere or in a realm, but in here, at the very soul of subjectivity" (1999: 124). In terms of politics, the generalized Foucaultian approach would maintain an analytical orientation toward localized 'micro-political' struggles, rather than state centred politics or global or radical revolutionary projects; instead of collective mobilisation and overall programs of another society, it would emphasize individual self-fashioning as an essentially political practice. Such a political practice would rest, not so much on emotionally engaged protest as on a belief in the emancipatory potentials of unsentimental, analytical critique. Attending to politics would, in brief, imply vigilant intellectual work to disturb the hegemony of fixed regimes by meticulously interrogating the power and knowledge intertwinements to keep the space free from the sedimentation of any totalising project (e.g. Connolly, 1993).

Public policy researchers indebted to Foucault have undertaken fruitful work in this vein to open up the spaces for autonomy and critical practice for professionals and recipients alike within social policy (Parton, 1996; Cruikshank, 1999; Karlsen and Villadsen, 2008; Nadesan, 2008). Yet, as we noted at the outset, this position has lead to a perhaps unwarranted restriction of the kinds of power that could be analysed and the stances that could be taken with respect to the state. A great deal of the existing work has pursued its critique of power by bringing into view the 'dark' disciplinary and pastoral 'underside' of the modern welfare state and can at best be read as a suspicious stance towards welfare arrangements, institutions and services. Foucault-inspired public policy observers have thus largely avoided the debate on the balance between universalism and particularism (e.g. Lister, 1998) and they have remained remarkably silent concerning rights, social legislation and welfare provision as supportive for critical practice in actual configurations of power. Foucault diverges, of course, sharply from a liberal concept of freedom as guaranteed by juridical and procedural limitations to the intrusion of the state. He seems to share a Marxian insight that, against material (as well as discursive) conditions of unfreedom, abstract rights are inadequate, and so expanding the room to manoeuvre for practices of self-definition and critique is a concrete task that needs to take shape in relation to context. And so, again, an argument is made for an emphasis on localized struggles and critique of institutions, rather than state-centred politics.

We contend that there is no reason to remain too faithful to Foucault's position on state, power and politics, which was indeed developed in a particular context, strongly shaped by Foucault's attempt to challenge Marxist theories of the state. If immanent critique means operating on the limits of the systems that one seeks to criticise, opening up spaces for 'thinking differently', there certainly must be multifarious ways of doing so. Attending to critical voices from the social policy field, and taking into account the recent embracing of post-structural thinking on power and diversity, we suggest two analytical displacements in the Foucaultian 'gaze' for public policy studies. First, more attention should be paid to the broader frameworks for thinking welfare reform and the welfare state as such, in particular, the ubiquitous concepts of diversity and the paradigmatic state-civil society binary. Second, a 'capability approach' should be included in considerations on how to facilitate practices of critique - that is, bring into view the discursive, material and institutional conditions necessary for individuals to critically question the truth through which they are being governed. The space of an article does not allow an exhaustive treatment of these suggestions, but the remainder provides some brief hints.

\subsection{First displacement}

Accompanying the success of postmodern theorising from the early 1980s onwards, political programs have emerged across European welfare states and beyond that rely upon concepts of 'diversity' or 'difference', i.e., in 
terms of a diversity of lifestyles, personal values, professional logics, community attitudes and more that should be taken into account and respected by cultural, social, and health policies (Rose, 1996; Vucina and Triantifillo, 2009; Andersen, 2009). What is voiced is a need for recognition of cultural differences, individuals' sense of belonging and people's actual values as a starting point for more responsive forms of policies and welfare provision, in particular in a context of growing multiculturalism and risks of social segregation in depraved urban areas of Europe (Isin and Turner 2002; Young, 1990). Arguably, however, differences are not just there to be respected; they are to an extent constructed in the image of the strategy. That differences are not simply natural givens, existing prior to their discursive mobilization, poses a number of problems for the policy observer, including those of a post-structural observance. Public policies that promote 'diversification' or 'pluralization' of welfare with a reference to cultural differences constitute, from our perspective, exactly one of those points of indistinction between power and critique.

Let us consider the problem of diversity with respect to our first suggestion to focus on the broader frameworks for conceptualizing the state and wide scale welfare reforms. It should immediately be noted that Foucault in fact sketches out something like this domain of interrogation in his recently translated lectures on governmentality from 1978-1979 (2008). Here, Foucault attempts to describe the practical and epistemological complex within which a modern conception of state and, in particular, the state/civil society binary could be envisioned. In this approach, he insists, one needs to avoid taking as an "already given object, notions such as the sovereign, sovereignty, the people, subjects, the state, and civil society, that is to say, all those universals employed by sociological analysis...in order to account for real governmental practice" (Foucault, 2008: 2). We take this to mean that, in the case of public policy reforms, for example, we must not take 'universals' such as state/civil society, public sector/third sector, or bureaucracy/amateurism as ontological points out departure, but should examine the functions such concepts play in concrete practices.

Indeed, that 'diversity' or 'pluralism' is constructed by, and not merely represented in, discourse, is evident in recent social policy programs for stronger involvement of the 'third sector' in welfare provision. Such programs have had a cross-national salience and they share the assumption that the welfare state should look towards its 'outside' - that is, civil society, voluntary agencies, or the third sector-for solutions to welfare problems that the state is not itself able to provide (Villadsen, 2009). As stronger hopes and more economic resources are being vested in the care providers of civil society, the need to critically interrogate the broader conceptual space for welfare reforms and its concepts of diversity is growing. This would be a way of exercising critique by 'turning diversity upon itself', as it were, using post-structural deconstruction to interrogate the instrumentalization of one of its own favourite thought figures.

\subsection{Second displacement}

Our dislocation of the Foucaultian position on public policy concerns a stronger emphasis on the conditions for exercising critique. The problem is how to bring into view the discursive, material and institutional conditions that would enable individuals to exercise Foucaultian critique, in terms of critically questioning the truth through which they are being governed (Foucault, 1997: 32). Now, the policy emphasis on 'diversity' seems to repeat itself with respect to groups and users in recent public policy programs and service arrangements. Special housing arrangements are constructed for particular types of homeless; health promotion encourages individually defined health objectives; new dialogue techniques aim to facilitate each user's particular view; and so on. Admittedly, concomitant processes of standardization take place in service provision, but we feel that this has already received critical attention and that the diversity emphasis is more difficult to grasp since it is often framed in a post-structural vocabulary. In a crude form of post-structural policy, the world is one populated by a variety of particular elements (subjects or groups), each of which is capable of creating itself in its own particular way. An immediate concern is that by treating differences as natural, post structural inspired policy programs run the risk of reifying, and thus solidifying, differences produced through processes of social segregation and identification.

The position taken by Foucaultian studies of social policy has generally been one of a contestation of the social practices within which subjectivities are articulated with the aim of enhancing the subject's possibilities for creative (diversified) self-fashioning. We note that this model of selfhood as constant redetermination through transgression has certain affinities with a today commonplace conception of the welfare recipient or service user as someone who needs to learn not to be governed by external social forces. This would often mean to overcome learnt dependency and mental blockages, in particular, a negative self-esteem that prevents the recipient from realizing goals and dreams (Villadsen, 2007). Such a conception of 'mental barriers' has the function of rendering social conflicts and obstacles as internal, subjective ones and so severely reduces the possibilities for critique of existing arrangements. For this reason we need to carefully consider how to relate to this model of 
agent-centred self-definition limited only by the subjects' own submission to or compliance with social forces (Tobias, 2005: 69). More generally, this focus on the dominating and liberating effects connected to the subject's opportunities for creative self-fashioning, or in short Foucault preference of ethics over politics (Foucault, 1984b: 375), has been criticized by neo-marxists for, at best, promoting a naïve individual heroism and, at worst, suggesting an ironically detached de-politicizing conservatism (Eagleton, 1984).

This begs the question of whether we can be more precise about the conditions for engaging in critical practice. In this regard, consider Foucault's well-known reading of Kant's "What is Enlightenment?", which he summarized with the slogan 'dare to know' (Aude sapere) and the injunction to let yourself be governed by your own reason (Foucault 1984a). Enlightenment was, for Foucault, paradigmatic for the emergence of a new relationship between subjectivity, truth and power, since it marked the moment where subjects began to question the truth through which they were being governed (Foucault, 1997). Indeed, Foucault displays a particular interest in those moments and places in history where subjects in the shape of counter-hegemonic movements, for instance, religious reformations, succeeded in questioning the truths in which they were themselves implicated (Foucault, 2007a: 191).

In more general terms, this means that to be an agent capable of engaging in critique requires a capacity to utilize the power that circulates in all social configurations. Arguably, this requires cultural capital and a sense of the current stake of the game in the field one seeks to criticize - and so classic welfare state provision such as education, welfare, and access to information become crucial. Yet, it seems difficult to find support in Foucault for a social-democratic position that foregrounds the securing of citizens' welfare and well-being as a sine-qua-non condition for their exercise of critique. Foucault's followers have largely inherited this position. A noteworthy exception is Saul Tobias (2005), who calls on Foucaultians to shift their concept of freedom from personalized creative self-definition against forces of external constraint to a concern with the actual capability of subjects to undertake such a practice of freedom. Tobias used the 'capability approach' represented by Amartya Sen to argue for the need to treat humans as not only 'capable' but also as 'needy'. In this view, the undertaking of critical practice is circumscribed by a range of human functioning and needs that define the conditions under which any practice of self-creation can take place. In so far as these conditions are not met, they are unavoidable objects of political activism.

The description of such conditions of human well-being, however, calls for sociological methods that have so far been largely excluded from Foucaultian public policy studies. At this point, it is perhaps worthwhile to consider Bourdieu's critique of Foucault, i.e., the idea that Foucault's elaboration of highly sophisticated philosophy, which places itself uniquely above scientific theory and method, restricts his involvement in institutional contexts legitimized by social science (Callewart, 2006). Perhaps it is needed to emphasize that Foucault's approach should arguably be treated as a supplementary critique of the welfare state rather than as a substitution of critiques of material inequality. Then the latter may be addressed by Foucaultian studies, when necessary, without discarding his tools of epistemological critique. There is ample space for developing such approaches to public policies and administrative strategies from within a Foucaultian framework.

\section{Conclusion}

We are not, of course, the first to suggest that social analysis can take up instrumental or even ideological functions. We have merely tried to remind post-structuralists, particularly of the Foucaultian variety, that our approach is not inherently beyond appropriation for this function. Today, as we suggested, 'diversity' serves not only as a critique of welfare services but also as a key instrument for welfare reforms. This is the case whether such reforms are informed by the state/civil society-binary or the search for more 'user sensitive' service arrangements. As it becomes more difficult to distinguish governmental programs from the frameworks that are used by social scientists to analyse them, observers of public policy are increasingly likely to become implicit participants in the making and legitimating of political-administrative programs - or, putting it starker, to become ideologues. To be involved while at the same time eschewing instrumentalism, we must give greater consideration to what is at stake in the knowledge produced and its relation to wider social practices.

When governmental strategies begin to render instrumental 'respect for diversity', 'community values', 'identity-work', and even, critique, the post-structural approach reaches certain its limitations. Post-structural thinkers, however, have tended to either ignore power effects of their own thinking, or posited to 'open up the space for thinking differently', downplaying or denying the normative force of their analysis of power. Observers, we suggest, should be more attentive to the ways in which their analyses may feed into governmental strategies and shape public institutions. Post-structural analysis is not by its nature barred from feeding into the games that configure our relations of power. 
Foucault encouraged us to engage with the practice of critique of the present. In the future, we need to examine how concepts of diversity interlace with wide-scale policy reforms, institutional restructuring or the development of new power technologies for producing 'competent citizens'. Foucaultian style critical practice is merely a theoretical possibility if no effort is made to foster the concrete conditions for undertaking such practice. We need to identify the resources, tools and conditions that would be necessary for an effective contestation - even one that would utilize the multiple tactical possibilities of discourse. This concern is even more pertinent with respect to marginalised groups such as homeless, addicted or psychiatric patients, where the support of welfare institutions would be a first essential and necessary condition for their exercise of critical practice. If Foucault's thinking was never a monolithic whole but rather a series of strategic engagements with specific historical problems in specific social contexts there is no reason why elements from his analytical toolbox could not be mobilized in conjunction with concepts and tools from other sources. This, we contend, would be a way of being 'unfaithful' to the generalized Foucaultian position for public policy research, while remaining faithful to Foucault's call for critique in practice which takes aim of the present.

\section{References}

Andersen, N. A. (2009). Power at Play: The Relationships between Play, Work and Governance. Houndmills: Palgrave Macmillan.

Blackman, L. M. (1998). The Voice-hearing Experience. Nordiske Udkast, (1), 39-50.

Blackman, L. (2000). Ethics, Embodiment and the Voice-Hearing Experience. Theory, Culture and Society, 17(5), 55-74. http://dx.doi.org/10.1177/02632760022051392

Blackman, L. (2001). Hearing Voices: Embodiment and Experience. Free Association Books.

Barry, A., Osborne, T. \& Rose, N. (eds.) (1996). Foucault and Political Reason: Liberalism, NeoLiberalism and Rationalities of Government. London: UCL Press.

Callewart, S. (2006). Bourdieu, Critic of Foucault: The Case of Empirical Social Science against Double-Game-Philosophy. Theory, Culture \& Society, 23(6), 73-98. http://dx.doi.org/10.1177/026327640606977 6

Callinicos, A. (1991). Against Postmodernism: A Marxist Critique. Cambridge: Polity Press.

Coleman, R. \& Smith, M. (1997). Victim to Victor: working with voices. Gloucester: Handsell.

Connolly, W. (1993). Beyond Good and Evil: The Ethical Sensibility of Michel Foucault. Political Theory, 21(3), 365-389.

Cruikshank, B. (1999). The Will to Empower: Democratic citizens and other subjects. Ithaca: Cornell University Press.

Dean, M. (2002). Liberal government and authoritarianism. Economy and Society, 31(1), 37-61. http://dx.doi.org $/ 10.1080 / 03085140120109240$

Dean, M. (1999). Governmentality: Power and Rule in Modern Society. London: Sage Publications.

Eagleton, T. (1984). Capitalism, Modernism, Postmodernism. New Left Review, I (152), 60-73.

Foucault, M. (2008). The Birth of Biopolitics: Lectures at the College De France, 1978-1979. London: Palgrave Macmillan.

Foucault, M. (2007a). Security, Territory, Population: Lectures at the College De France, 1978-1979. London: Palgrave Macmillan.

Foucault, M. (2000). Useless to Revolt? In M. Foucault. Power: Essential Works of Foucault, 1954-1984, Vol. 3 (pp. 449-453). London: Penguin Books.

Foucault, M. (1997). What is Critique? S. Lotringer (ed). The Politics of Truth. New York: Semiotext(e).

Foucault, M. (1995). Discipline \& Punish: The Birth of the Prison. New York: Vintage Books.

Foucault, M. (1990). The History of Sexuality Vol. 1: An Introduction. New York: Vintage Books.

Foucault, M. (1988) Power and Sex. In: L.D. Kritzman (ed.). Michel Foucault: Politics, Philosophy, Culture. (pp. 110-124). New York: Routledge.

Foucault, M. (1984a). What is Enlightenment? In P. Rabinow (ed.). The Foucault Reader (pp. 32-50). New York: Pantheon Books. . 
Foucault, M. (1984b). Politics and Ethics: An interview. In P. Rabinow (ed.). The Foucault Reader (pp. 373-380). New York: Pantheon Books.

Foucault, M. (1982). The Subject and Power. Critical Inquiry, 8(4), 777-795. http://dx.doi.org/10.1086/448181

Foucault, M. (1980a). Truth and Power. In M. Foucault (1980). Power/knowledge: Selected interviews \& other writings by Michel Foucault (pp. 109-133). New York: Pantheon Books.

Foucault, M. (1980b). Two Lectures. In M. Foucault. Power/knowledge: Selected interviews \& other writings by Michel Foucault. (pp. 78-108). New York: Pantheon Books.

Gordon, C. (1991). Governmental Rationality: An Introduction. In G. Burchell, C. Gordon \& P. Miller (eds.). The Foucault Effect. Studies in Governmentality ( pp.1-52). Chicago: The University of Chicago Press.

Hardt, M. \& Negri, A. (2001). Empire. Boston: Harvard University Press.

Hearn, J. (1982). Radical Social Work: Contradictions, Limitations and Political Possibilities. Critical Social Policy, 2(4), 19-34. http://dx.doi.org/10.1177/026101838200200404

Honneth, A. (2000). Pathologien der individuellen Freiheit: Hegels Zeitdiagnose und die Gegenwart. In J. Huber (ed.). Darstellung: Korrespondenz. Zurich: Interventionen 9.

Isin, E. F. \& Turner, B. S. (2002). Handbook of citizenship studies. London: Thousand Oaks.

Jameson, F. (1984). Post-modernism or the cultural logic of late capitalism. New Left Review, (146), 53-94.

Karlsen, M. P. \& Villadsen, K. (2008). Who should do the talking: The proliferation of dialogue as governmental technology. Culture \& Organization, 14(4), 345-363. http://dx.doi.org/10.1080/14759550802489680

Laclau, E. (1977). Politics and Ideology in Marxist Theory: Capitalism, Fascism, Populism. London: Verso.

Lister, R. (1998). Citizenship and Difference: Towards a Differentiated Universalism. European Journal of Social Theory, 1(1), 71-90. http://dx.doi.org/10.1177/136843198001001006

Nadesan, M. H. (2008). Governmentality, biopower, and everyday life. New York: Routledge.

Parton. N. (1996) (ed.). Social Theory, Social Change and Social Work. London: Routledge.

Rose, N. (1996). The Death of the Social? Refiguring the territory of government. Economy and Society. 25(3), 327-356. http://dx.doi.org/10.1080/03085149600000018

Rose, N. \& Miller, P. (1992). Political Power beyond the State: Problematics of Government. The British Journal of Sociology, 43(2), 173-205. http://dx.doi.org/10.2307/591464

Stäheli, U. (2007). Poststrukturalismus und Ökonomie: Eine programmatische Skizze der Affektivität ökonomischer Prozesse. In C. Arni et al. (eds.). Der Eigensinn des Materials (pp. 503-520). Frankfurt/M.: Stroemfeld.

Taylor-Gooby. (1994). Postmodernism and Social Policy: A Great Leap Backwards? Journal of Social Policy, 23(3), 385-404. http://dx.doi.org/10.1017/S0047279400021917

Villadsen, K. (2007). The Emergence of 'Neo-Philanthropy': A new discursive space in welfare policy? Acta Sociologica, 3(50), 309-923. http://dx.doi.org/10.1177/0001699307080938

Villadsen, K. (2009). The 'Human' Touch: Voluntary organizations as rescuers of social policy? Public Management Review, 11(2), 217-234. http://dx.doi.org/10.1080/14719030802685289

Vucina, N. \& Triantafillou, P. (2009). HIV, Constructionism and Biopower, Distinktion, (18), 29-46.

Young, I. M. (1990). Justice and the politics of difference. Princeton: Princeton University Press.

Žižek, S. (1999). The Ticklish Subject: The Absent Centre of Political Ontology. London: Verso. 